\title{
IMPLEMENTASI AFFIRMATIVE ACTION KUOTA PEREMPUAN DALAM PARTAI POLITIK DAN LEMBAGA PERWAKILAN RAKYAT DAERAH (Studi di Wilayah Kota Malang)
}

\author{
Oleh : \\ Sirajuddin*, Adiloka Sudjono*
}

\begin{abstract}
In the 2009 legislative general election, there were 793 definitive candidates, consisting of 528 men and 265 women. Therefore, the average percentage of definitive female candidates from the whole parties was $33 \%$ and in general it seems that the percentage was above $30 \%$. But, an affirmative action as stated on the law on the election of the house of representative members in Malang city in 2009 was not reached, since the number of the elected female legislative representative was still under quota of 30\%. Factors causing such less optimum affirmative action in political parties and the house of representative in Malang city are as follows: (1) the political context dominated by men so that the women's interest was less accommodated. (2) the social context dominated by men so this resulted in masculine practices and (3) the cultural context dominated by a patriarchal tradition resulting a social construction on the division of men and women, and the legal factor through the decision of the constitutional court that did not condition the legislative candidates based on the highest voters, instead of the number order.
\end{abstract}

Kata Kunci: affirmative action, perempuan, partai politik, lembaga perwakilan rakyat daerah.

\section{Pendahuluan}

Untuk mengatasi kondisi eksploitasi dan diskriminasi terhadap perempuan yang dikonstruksi melalui kebijakan hukum maka dibutuhkan advokasi kebijakan bagi kaum perempuan. Salah satu bentuknya adalah dengan perlakuan yang tidak setara untuk jangka waktu dekat. Hal ini dikenal sebagai tindakan afirmatif (affirmative action) atau diskriminasi positif(untuk kepentingan perempuan). ${ }^{1}$

* Dosen Fakultas Hukum Univ. Widyagama Malang

** Dosen Fakultas Hukum Univ. Widyagama Malang

${ }^{1}$ Lihat Rhona K. M. Smith, dkk, 2008. Hukum Hak Asasi Manusia, Yogyakarta: Pusat Studi HAM UII Yogyakarta, hlm. 149
Mendorong kesetaraan dalam kehidupan politik berlangsung terus menerus. Sebuah kondisi awal yaitu Konvensi PBB tentang Hak Berpolitik untuk Perempuan (1952), meletakkan dasar untuk perkembangan masa depan. Kebanyakan negara sekarang membolehkan perempuan untuk memilih dan di banyak negara perempuan telah memegang jabatan politik walaupun sedikit dari mereka kesetaraan perwakilan dalam susunan parlemen. ${ }^{2}$ PBB sendiri sekarang terlibat dalam pengarusutamaan

${ }^{2}$ Lihat http://www.ipu.org, the inter-Parliamnetary Union yang mempunyai informasi statistik tentang perwakilan perempuan dan laki-laki dalam badan-badan parlemen seluruh dunia. 
gender sebagai pelaksanaan agenda Beijing, yang berjuang untuk memastikan bahwa perempuan dapat terwakili dalam semua tingkat dalam organisasi tersebut

Peningkatan kesetaraan gender menjadi salah satu isu penting dalam perubahan Undang Undang Nomor 31 Tahun 2002. Adapun ketentuan Undang Undang Nomor 2 Tahun 2008 yang berkaitan dengan peningkatan kesetaraan gender dimulai dari Pasal 2 ayat (5) yang menentukan : "kepengerusan partai politik tingkat pusat sebagaimana dimaksud pada ayat (3) disusun dengan menyertakan paling rendah 30\% keterwakilan perempuan". Pelanggaran terhadap ketentuan Pasal 2 dikenai sanksi administratif berupa penolakan pendaftaran partai politik sebagai badan hukum oleh Departemen Hukum dan HAM. ${ }^{3}$

Dengan sistem kuota diharapkan nantinya posisi dan perspektif perempuan akan lebih terwakili. Keputusan-keputusan yang dihasilkan juga harus ramah terhadap keterlibatan perempuan, tidak hanya dibidang politik, tetapi juga sosial, ekonomi dan budaya. Ini mengingat keputusan perlemen mencakup semua aspek kehidupan berbangsa dan bernegara. Keputusan-itu juga harus bisa mengembangkan ruang gerak perempuan dalam sektor publik dan bisa membawa isu kesetaraan dalam setiap keputusan yang dihasilkan. ${ }^{4}$

Pengaturan kuota perempuan di parlemen (UU No. 10 tahun 2008) yang diperkuat dengan kebijakan kuota perempuan dalam partai politik (UU No. 2 tahun 2008) menyiratkan bahwa di dalam pencapaian representasi perempuan diperlukan supporting system yang memungkinkan perempuan memiliki akses dan kesempatan untuk berkiprah pada panggung politik. Oleh karena kedua UU saling terkait, pemahaman mengenai relasi kedua UU tersebut dalam menganalisis peraturan representasi politik perempuan menjadi amat penting.

${ }^{3}$ Lihat A.A. Oka Mahendra, 2008. "Paradigma Baru UU Nomor 2 Tahun 2008 tentang Partai Politik" artikel dalam Jurnal Legislasi Indonesia, Vol. 5 No. 1 Maret 2008, hlm. 81-89

${ }^{4}$ Sistem kuota bisa meningkatkan secara dramatis keterwakilan perempuan di sejumlah negara . kini lima negara Skandinavia, Denmark, Finlandia, Easlandia, Norwegia dan Swedia yang selama ini mendominasi tingginya dominasi perempuan mendapat tantangan baru. Di Afghanistan, misalnya negara dan penafsiran agama yang konservatif untuk perempuan dan angka melek huruf untuk perempuan yang sangat rendah, perempuan menempati 27,7 persen kursi parlemen. Lihat Lily Zakiyah Munir, 2009. "Tantangan Kuota Perempuan" Artikel dalam Harian Kompas, Senin, 30 Maret 2009.
Peraturan yang melulu fokus pada angka melalui kuota tidak akan berarti apa-apa jika tidak diperkuat dengan aksentuasi pada perluasan akses dan keterlibatan perempuan (women's access and engagement). Bila tidak, hal ini dapat menggiring kebijakan kuota pada jebakan yang disebut Carol Bacchi sebagai "the politic of presence" atau "politik kehadiran", yakni sebuah kebijakan yang merasa cukup dengan kehadiran kaum perempuan dalam lembaga politik tanpa perlu secara serius menelusuri apakah kehadiran tersebut telah dan akan berkontribusi bagi perubahan kebijakan yang lebih gender-aware. ${ }^{5}$

Beberapa bulan menjelang Pemilu (09 April 2009), Mahkamah Konstitusi mengeluarkan Putusan Nomor 22-24/PUU-VI/2008 tanggal 23 Desember 2008 yang menyatakan sistem pendaftaran calon tertutup bukanlah preferensi suara terbanyak sebagaimana diberikan pemilih dan merupakan pelanggaran hak pemilih untuk memilih wakil rakyat yang diinginkan.

Sistem nomor urut yang mengakomodasikuota 30 persen bagi perempuan, seperti dalam UU Pemilu menjadi tidak berlaku. DataKPUyang diolah www.pemilu.asia menunjukkan, penempatan calon anggota legislatif perempuan pada urutan ketiga sebanyak 1.052 dibandingkan dengan lelaki 674 calon. Pada urutan pertama caleg perempuan 505 orang dan lelaki 2.259 orang. Keputusan MK tersebut membuat penyusunan urutan ini tidak relevan lagi.

\section{PERUMUSAN MASALAH}

Adapun rumusan masalah dalam penelitian ini adalah; (1) Bagaimanakah Implementasi Affirmative Action Kuota Perempuan dalam Partai Politik dan lembaga perwakilan rakyat di Wilayah Kota Malang?; (2) Faktor-faktor Apakah yang menghambat Implementasi Affirmative Action Kuota Perempuan dalam Partai Politik dan lembaga perwakilan rakyat di Wilayah Kota Malang?; (3) Strategi apakah yang dilakukan oleh kaum perempuan, LSM, Ormas dan organisasi yang berbasis perempuan dalam implementasi Affirmative Action Kuota Perempuan dalam Partai Politik dan lembaga perwakilan rakyat di Wilayah Kota Malang?

${ }^{5}$ Ibid 


\section{METODE PENELITIAN}

Penelitian ini dilakukan dengan pendekatan yuridis sosiologis (socio legal research). Pada tahap pertama penelitian ini mengungkap implementasi affirmative action kuota perempuan dalam partai politik dan lembaga perwakilan rakyat daerah dan tahap kedua adalah penelitian untuk mengungkapkan data dan informasi yang ada di lapangan berkaitan dengan faktor-faktor penghambat implemetasi sekaligus upaya-upaya yang dilakukan oleh berbagai pihak dalam implementasi affirmative action kuota perempuan dalam partai politik dan lembaga perwakilan rakyat. Penelitian lebih diarahkan pada analisis kualitatif. Karena itu penggalian data dan informasi dilakukan dengan menggunakan studi kasus.

Sesuai dengan perspektif penelitian, dimana penelitian ini akan mengkaji tentang implementasi affirmative action kuota perempuan dalam partai politik dan lembaga perwakilan rakyat daerah maka Penelitian ini dilakukan Kota Malang

Dipilihnya Kota Malang sebagai Lokasi Penelitian Karena merupakan salah satu Kota sudah mulai tumbuh menjadi kota metropolis yang sarat dengan berbagai persoalan sosial termasuk eksploitasi dan diskriminasi terhadap perempuan. Disamping itu di Kota Malang berkembang berbagai lembaga pendidikan dan Lembaga Swadaya Masyarakat yang kian kritis dengan berbagai kebijakan Pemerintah Kota Malang. Sehingga partisipasi masyarakat dalam pembangunan terutama setelah diterapkan kebijakan otonomi daerah semakin intens.

\section{HASIL DAN PEMBAHASAN}

1. Implementasi Affirmative Action Kuota Perempuan dalam Partai Politik dan lembaga perwakilan rakyat di Wilayah Kota Malang

Sudah cukup banyak konvensi internasional yang difasilitasi Perserikatan Bangsa-Bangsa (PBB) dan diratifikasi banyak negara, termasuk Indonesia, yang menyebutkan perempuan memiliki hak-hak politik yang sama dengan laki-laki. Dengan kata lain, negara tidak boleh mendiskriminasi perempuan dengan laki-laki. Dengan kata lain, negara tidak boleh menidiskriminasi perempuan akan hak-hak politiknya, karena hak-hak politik adalah bagian tak terpisahkan dari hak-hak asasi manusia. Diratifikasinya konvensi Perserikatan Bangsa-Bangsa (PBB) mengenai penghapusan segala bentuk diskriminasi terhadap perempuan melalui Undang-Undang(UU) Nomor 7 Tahun 1984, menjadi landasan perjuangan isu kesetaraan gender. Walaupun tidak ada sanksi berat bagi negara yang meratifikasi konvensi ini (sebatas dipermalukan dalam sidang PBB).

\section{Tabel 1}

Proporsi Perempuan dalam Lembaga Legislatif di Indonesia

\begin{tabular}{|c|c|c|c|c|c|}
\hline Pemilu & $\begin{array}{c}\text { Total } \\
\text { Anggota }\end{array}$ & Laki-laki & $\begin{array}{c}\text { Porsentase } \\
\text { Laki-laki }\end{array}$ & Perempuan & $\begin{array}{c}\text { Porsentase } \\
\text { Perempuan }\end{array}$ \\
\hline 1955 & 272 & 255 & 93.7 & 17 & 6.3 \\
\hline 1971 & 460 & 437 & 94.9 & 23 & 5.1 \\
\hline 1977 & 460 & 427 & 92.8 & 33 & 7.2 \\
\hline 1982 & 460 & 421 & 91.5 & 39 & 8.5 \\
\hline 1987 & 500 & 450 & 90.0 & 50 & 10.0 \\
\hline 1992 & 500 & 446 & 89.2 & 54 & 10.8 \\
\hline 1997 & 500 & 442 & 88.4 & 58 & 11.6 \\
\hline 1999 & 500 & 455 & 91.0 & 45 & 9.0 \\
\hline 2004 & 550 & 485 & 88.19 & 65 & 11.81 \\
\hline
\end{tabular}

- $\quad$ Sumber: Litbang Kompas, 24 Februari 2003 dan KPU 2004 
Dari penyelenggaraan pemilu yang satu ke pemilu yang lain, sebagaimana dapat dilihat dari tabel 1 , menunjukkan bahwa peningkatan representasi perempuan dalam aktifitas politik sangat lambat. Partisipasi politik perempuan pada Pemilu 2004, meski sudah ada kuota $30 \%$, hanya meningkat $0.01 \%$ dibandingkan dengan Pemilu 1992. Sedangkan bila dibandingkan dengan Pemilu 1999 mengalami peningkatan $2.8 \%$. Pada Pemilu 2004, jumlah anggota legislatif perempuan berjumlah 65 orang atau $11.81 \%$, sedangkan sebagian besar $(88.19 \%)$ adalah laki-laki dari jumlah keseluruhan (550 orang).

Salah satu lembaga politik yang menjadi ukuran demokrasi adalah lembaga parpol. Setidaknya parpol menjadi lembaga politik yang jauh dinamis dibandingkan dengan lembaga formal lainnya, sebab di dalam partai secara konseptual dilaksanakan berbagai fungsi politik Parpol sebagai salah satu indikator berjalannya mesin demokrasi tentunya tidak diskriminatif dalam merekrut atau mengkader anggota-anggotanya, khususnya secara gebder. Namun dalam kenyataan, masih ada partai yang mengadopsi nilai-nilai patriarki, sehingga akses perempuan ke parpol tersebut sangat terbatas. Diskriminasi yang bersumber pada nilai-nilai patriarki ini sampai kapanpun bila dibiarkan akan menjadi handicap untuk akses politik perempuan di dalam parpol.

Jika partisipasi politik diukur dengan kuota $30 \%$, maka dalam konteks ini peran partai politik sangatlah penting. Determinasi peran partai politik untuk meningkatkan partisipasi politik perempuan antara lain bisa ditunjukkan dari fungsi yang dijalankan parpol, sosialisasi politik dan rekrutmen politik. Oleh karena itu, maka sesungguhnya dunia politik merupakan institusi politik yang paling dinamis dibandingkan dengan lembaga-lembaga formal lainnya (Windyastuti, 2004).

Memperhatikan fungsinya yang strategis untuk meningkatkan partisipasi politik perempuan, partai politik seharusnya terbuka untuk memberikan peluang kepada semua warga, terutama perempuan. Namun, dalam prakteknya masih banyak parpol yang karena masih mengadopsi nilai-nilai patrirki enggan melakukannya dan karena itu membatasi akses perempuan untuk berpartisipasi ke dunia publik, khususnya parpol. Kondisi parpol yang masih patriarchy oriented ini sudah tentu akan menjadi handicap untuk akses politik perempuan di masa mendatang.

Lolosnya UU Pemilu Nomor 12 Tahun 2003 bolehjadi menjadi entrypoint perempuanuntuk dapat lebih banyak berkiprah dalam dunia publik melalui parpol. Pencantuman antuman secara tegas kuota $30 \%$ untuk perempuan sebagaimana tertera dalam pasal 65 ayat 1 adalah sebagai bentuk affirmative action yang berlaku dalam jangka waktu tertentu.

Berbeda dengan negara lain yang rata-rata keterwakilannya perempuan sekitar 35\%, di Indonesia keterwakilan politik perempuan masih rendah. Di bawah ini adalah data yang menunjukkan keterwakilan politik di berbagai negara.

Tabel 2

Proporsi Keterwakilan Perempuan dalam Mejelis Rendah Nasional

\begin{tabular}{|l|c|l|}
\hline \multicolumn{1}{|c|}{ Negara } & $\begin{array}{c}\text { Proporsi Perempuan } \\
\text { Dalam Mejelis Rendah }\end{array}$ & \multicolumn{1}{c|}{ Sistem Pemilihan Umum } \\
\hline Swedia & 42,7 & Representasi Proporsional/campuran \\
\hline Denmark & 37,4 & Representasi Proporsional \\
\hline Noerwegia & 36,4 & Representasi Proposional \\
\hline Jerman & 30,9 & Representasi Wakil Campuran \\
\hline Selandia Baru & 30,8 & Representasi Wakil Campuran \\
\hline Afrika Selatan & 29,8 & Representasi Proporsional \\
\hline Mozambik & 30,0 & Representasi Proposional \\
\hline
\end{tabular}

Sumber: Chusnul Mar'iyah, Kompas 11 Februari 2004 
Menjelang pemilu 2009, terdapat dua peraturan perundang-undangan penting terkait dengan kuota perempuan dalam panggung politik Indonesia. Kedua peraturan tersebut adalah Undang Undang No. 2 Tahun 2008 Tentang Partai Politik (UU Parpol) dan Undang-undang No. 10 tahun 2008 Tentang Pemilihan Umum(UU Pemilu).UU Pemilu merupakan kebijakan inti perihal isu representasi politik perempuan yang didalamnya ditegaskan mengenai kuota perempuan di parlemen. Sedangkan UU Parpol menjadi basis bagi implementasi UU Pemilu karena Undang-Undang tersebut mengatur representasi perempuan di partai politik.

Pemilu 2009 merupakan Pemilu ketiga di era reformasi. Dua pemilu sebelumnya secara teknis prosedural berjalan dengan cukup baik. Keberhasilan dua kali penyelenggaraan tersebut menjadikan Indonesia berhasil melalui fase kritis. Arus balik atau stagnasi transisi demokratisasi tidak terjadi.

Berdasarkan data yang diperoleh dari KPUD Kota Malang, bahwa pada tahun 2009 jumlah caleg tetap adalah 793 orang yang terdiri atas 528 lakilaki dan 265 perempuan. Sehingga rata-rata prosentase caleg perempuan seluruh parpol tersebut adalah $33 \%$, dan pada umumnya memang nampak bahwa parpol memiliki prosentase di atas quota $30 \%$ (sesuai Pasal 53 UU Nomor10 Tahun 2008). ${ }^{6}$

Dalam penyelenggaraan Pemilu anggota legislatif tahun 2009, tepatnya tanggal 16 Mei 2009, KPU Kota Malang telah melaksanakan Rapat Pleno untuk menetapkan caleg terpilih Anggota DPRD Kota Malang hasil Pemilu Tahun 2009 disetiap daerah pemilihan (Dapil), sebagaimana terinci pada lampiran 1.1 sampai dengan 1.5.. Pada pemilu legislatif2009 ini, di Kota Malang terdapat 5 dapil, yakni Dapil 1 untuk wilayah Kedungkandang, Dapil 2 untuk wilayah Sukun, Dapil 3 untuk wilayah Klojen, Dapil 4 untuk wilayah Blimbing, dan Dapil 5 untuk wilayah Lowokwaru.

Berdasarkan rincian data Penghitungan Perolehan Suara Sah dan Peringkat Suara Sah Calon Anggota DPRD Kota Malang Pemilu Tahun 2009, maka berkaitan dengan upaya affirmative action, maka dapat dibuat tabel untuk mengetahui dengan jelas tentang nomor urut daftar calon tetap (DCT) dan jumlah caleg perempuan terpilih sebagai berikut:

Tabel 3

Jumlah Calon Legislatif Terpilih Pemilu anggota DPRD Kota Malang Tahun 2009 Berdasarkan Nomor Urut dan Jenis Kelamin

\begin{tabular}{|c|c|c|c|c|c|c|}
\hline \multirow{2}{*}{$\begin{array}{l}\text { Daerah } \\
\text { Pemilihan }\end{array}$} & \multirow{2}{*}{ No } & \multirow{2}{*}{$\begin{array}{l}\text { Nama } \\
\text { Parpol }\end{array}$} & \multirow{2}{*}{$\begin{array}{c}\text { Nama } \\
\text { Calon Terpilih }\end{array}$} & \multirow{2}{*}{$\begin{array}{l}\text { No. Urut } \\
\text { DCT }\end{array}$} & \multicolumn{2}{|c|}{ Jenis Kelamin } \\
\hline & & & & & Lk & $\mathrm{Pr}$ \\
\hline \multirow{9}{*}{1} & 1 & $\begin{array}{l}\text { Partai } \\
\text { Gerindra }\end{array}$ & Drs. Salamet & 2 & 1 & \\
\hline & 2 & PKS & M. Isa Anshori & 2 & 1 & \\
\hline & 3 & PAN & Lookh. Mahkhfudz & 2 & 1 & \\
\hline & 4 & PKB & H. Abd. Rahman & 1 & 1 & \\
\hline & 5 & $\begin{array}{l}\text { Partai } \\
\text { Golkar }\end{array}$ & $\begin{array}{l}\text { Healthy Lukistiono, } \\
\text { SE.,MSi }\end{array}$ & 5 & 1 & \\
\hline & 6 & PDIP & $\begin{array}{l}\text { Drs. Nuruddin } \\
\text { Huda }\end{array}$ & 5 & 1 & \\
\hline & 7 & PDIP & Suprapto, SH & 1 & 1 & \\
\hline & 8 & $\begin{array}{l}\text { Partai } \\
\text { Demokrat }\end{array}$ & $\begin{array}{l}\text { Hj. Wiwik Hendri } \\
\text { Astuti }\end{array}$ & 2 & & 1 \\
\hline & 9 & $\begin{array}{l}\text { Partai } \\
\text { Demokrat }\end{array}$ & Mudjiono, SH & 1 & 1 & \\
\hline
\end{tabular}

${ }^{6}$ Joko Widarto, 2009. "Implikasi Hukum Putusan MK Nomor 22-24/PUU-VI/2008 terhadap Upaya Affirmative Action dalam UU No. 10 Tahun 2008 di Kota Malang" artikel dalam Jurnal Konstitusi, kerjasama MK RI dengan PKK Univ. Kanjuruhan Malang, Vol. II No. 1, Juni 2009 
Widya Yuridika Jurnal Hukum. Volume 1 / Nomor 2 / Desember 2018

\begin{tabular}{|c|c|c|c|c|c|c|}
\hline \multirow{10}{*}{2} & 1 & $\begin{array}{l}\text { Partai } \\
\text { Hanura }\end{array}$ & $\begin{array}{l}\text { Yaqud Ananda } \\
\text { Gudban, SST,MM }\end{array}$ & 3 & & 1 \\
\hline & 2 & $\begin{array}{l}\text { Partai } \\
\text { Gerindra }\end{array}$ & $\begin{array}{l}\text { RM. Een } \\
\text { Ambarsari, Dra }\end{array}$ & 2 & & 1 \\
\hline & 3 & PKS & Nurul Ar'baati, S.Pt & 1 & & 1 \\
\hline & 4 & PKB & $\begin{array}{l}\text { H. Siswo Waroso, } \\
\text { SE }\end{array}$ & 2 & 1 & \\
\hline & 5 & $\begin{array}{l}\text { Partai } \\
\text { Golkar }\end{array}$ & $\begin{array}{l}\text { Ir. Sofyan Edi } \\
\text { Jarwoko }\end{array}$ & 1 & 1 & \\
\hline & 6 & PDS & $\begin{array}{l}\text { Budianto Wijaya, } \\
\text { SH }\end{array}$ & 11 & 1 & \\
\hline & 7 & PDIP & $\begin{array}{l}\text { Drs. Eka Satria } \\
\text { Gautama, MH }\end{array}$ & 1 & 1 & \\
\hline & 8 & PDIP & $\begin{array}{l}\text { Kwindya Dwi } \\
\text { Karana }\end{array}$ & 4 & 1 & \\
\hline & 9 & $\begin{array}{l}\text { Partai } \\
\text { Demokrat }\end{array}$ & Sulik Listyowati, SH & 1 & & 1 \\
\hline & 10 & $\begin{array}{l}\text { Partai } \\
\text { Demokrat }\end{array}$ & $\begin{array}{l}\text { Christea } \\
\text { Frisdiantara, } \\
\text { SE.MM }\end{array}$ & 6 & 1 & \\
\hline \multirow{7}{*}{3} & 1 & PKS & Ahmadi, S.Si & 1 & 1 & \\
\hline & 2 & PAN & Syaiful Rusdi, S.Pd & 1 & 1 & \\
\hline & 3 & PKB & Arief Wahyudi, SH & 3 & 1 & \\
\hline & 4 & $\begin{array}{l}\text { Partao } \\
\text { Golkar }\end{array}$ & $\begin{array}{l}\text { Rahayu Sugiarti, } \\
\text { S.Sos }\end{array}$ & 1 & & 1 \\
\hline & 5 & PDIP & Dra. Sri Untari & 2 & & 1 \\
\hline & 6 & $\begin{array}{l}\text { Partai } \\
\text { Demokrat }\end{array}$ & Hj. Suharni, SH & 1 & & 1 \\
\hline & 7 & $\begin{array}{l}\text { Partai } \\
\text { Demokrat }\end{array}$ & Hery Subiantono & 2 & 1 & \\
\hline \multirow{9}{*}{4} & 1 & PKS & Choirul Amri, SE & 1 & 1 & \\
\hline & 2 & PAN & Subur Triono, SE & 5 & 1 & \\
\hline & 3 & PKB & H. Rasmuji & 3 & 1 & \\
\hline & 4 & $\begin{array}{l}\text { Partai } \\
\text { Golkar }\end{array}$ & $\begin{array}{l}\text { Prof. DR. H. } \\
\text { Bambang Satriya, } \\
\text { SH, MH }\end{array}$ & 1 & 1 & \\
\hline & 5 & PDIP & Drs. Abd. Hakim & 1 & 1 & \\
\hline & 6 & PDIP & Tri Yudiani & 6 & & 1 \\
\hline & 7 & $\begin{array}{l}\text { Partai } \\
\text { Demokrat }\end{array}$ & $\begin{array}{l}\text { Dra. Fransiska } \\
\text { Rahayu Budiwiarti }\end{array}$ & $2^{\circ}$ & & 1 \\
\hline & 8 & $\begin{array}{l}\text { Partai } \\
\text { Demokrat }\end{array}$ & Suyatno & 3 & 1 & \\
\hline & 9 & $\begin{array}{l}\text { Partai } \\
\text { Demokrat }\end{array}$ & $\begin{array}{l}\text { Suprasnowo } \\
\text { Moenadjam }\end{array}$ & 1 & 1 & . \\
\hline \multirow{4}{*}{$\cdot 5$} & 1 & PKPB & H. Agus Suryanto & 2 & 1 & \\
\hline & 2 & PKS & $\begin{array}{l}\text { Bambang Triyoso, } \\
\text { SE, MM }\end{array}$ & 1 & 1 & \\
\hline & 3 & PAN & $\begin{array}{l}\text { H.Pujianto, SE, } \\
\text { M.Hum }\end{array}$ & 1 & 1 & \\
\hline & 4 & PKB & Drs. Sutiaji & 1 & 1 & \\
\hline
\end{tabular}




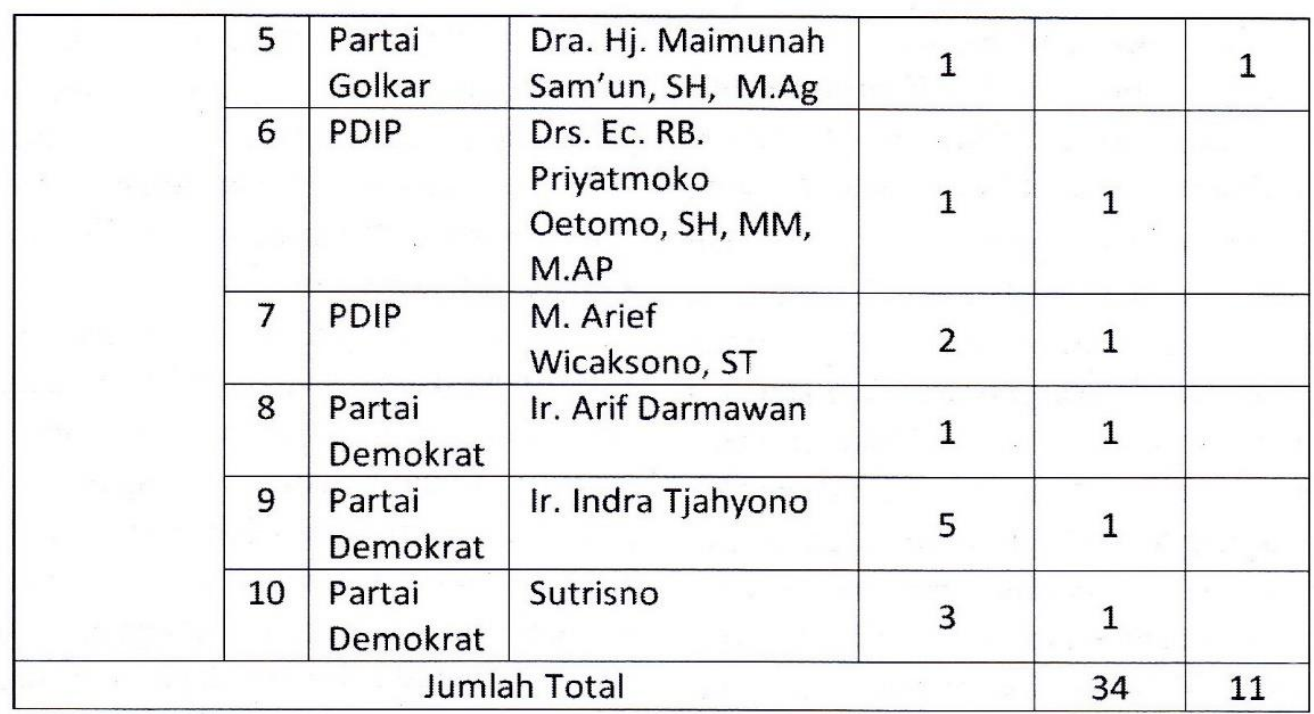

Berdasarkan data tabel 3 di atas, maka nampak bahwa jumlah caleg terpilih pada Pemilu DPRD Kota Malang Tahun 2009 adalah sebanyak 34 caleg laki-laki (76\%) dan 11 caleg perempuan (24\%), sehingga berjumlah 45 orang caleg terpilih. Dengan demikian upaya affirmative action sebagaimana dimaksud UU No.10 Tahun 2008 dalam Pemilu DPRD Kota Malang Tahun 2009 tidak tercapai karena jumlah caleg perempuan terpilih masih di bawah quota $30 \%$ (dalam rangka keterwakilan perempuan parlemen Kota Malang).

Diantara ke- 45 caleg terpilih ini, sebagian besar adalah caleg pada posisi nomor urut 1,2, dan 3 \{note:sistem zipper-diantara 3 caleg terdapat sekurang-kurangnya 1 caleg perempuan; dalam arti nomor "jadi"' $\}$, yaitu sebanyak 39 caleg atau sebesar $87 \%\{(39: 45) X 100 \%\}$. Caleg terpilih pada nomor urut 4 tidak ada. Caleg terpilih pada nomor urut 5 sebanyak 4 orang atau sebesar $9 \%$. Dan caleg terpilih pada nomor urut 6 hanya sejumlah 2 orang atau sebesar $4 \%$. Hal ini mengindikasikan secara jelas bahwa nomor urut sebagaimana dimaksud Pasal 214 UU No.10 Tahun 2008 (yang "dibatalkan" oleh Putusan MK No.22-24/PUU-VI/2008) merupakan faktor utama pemilih dalam menentukan pilihan caleg.

Sesuai tabel, jumlah caleg perempuan terpilih dalam Pemilu DPRD Kota Malang 2009 adalah 11 orang caleg dari 45 caleg terpilih atau sebesar $24 \%$. Karena jumlah ini masih di bawah Quota 30\% keterwakilan perempuan, berarti upaya affirmative action kuota perempuan dalam lembaga perwakilan daerah tidak tercapai.
Berkaitan dengan persoalan ini, ketua Fatayat NU Kota Malang Dewi Masyitah menyatakan:

Pelaksanaan dari affirmative action ini belum nampak peran perempuan dalam lembaga legislatif, salah satu contohnya ketika melakukan pembahasan mengenai kebijakan tentang pengaturan pasar, tapi tidak nampak peran legislatif (khususnya yang perempuan) untuk ikut menentukan kebijakan tersebut padahal seperti kita ketahui bahwa mayoritas yang terlibat di pasar baik itu pedagang ataupun pembeli adalah kaum perempuan ${ }^{7}$

Perlu juga diungkapkan disini bahwa dalam penyelenggaraan Pemilu 2009 diwarnai dengan pelanggaran hak pilih warga secara masif. Banyak warga yang tidak dapat menggunakan hak pilihnya karena naman Pemilu 2009 diwarnai dengan pelanggaran hak pilih warga secara masif. Banyak warga yang tidak dapat menggunakan hak pilihnya karena namanya tidak terdaftar dalam daftar pemilihan umum. Komisi Pemilihan Umum menolak disalahkan (Kompas, 15/4/09), pemerintah menolak bertanggungjawab, bahkan menuduh rakyat ikut andil dalam kekisruhan daftar pemilih tetap. ${ }^{8}$

Perlu juga disadari bahwa penyebab carutmarutnya DPT antara pemerintah dan KPU berakar pada rendahnya kesadaran penduduk untuk melaporkan kejadian lahir, mati, pindah dan datang yang menyebabkan orang yang tidak melapor tidak terdaftar pada data administrasi kependudukan (DP4). Dilain pihak, KPU yang dituntut untuk memutahirkannya diragukan kinerjanya. ${ }^{9}$

\footnotetext{
${ }^{7}$ Wawancara dengan Ibu Dewi Masyitah, Ketua Fatayat NU Kota Malang tanggal 26 Oktober 2010

${ }^{8}$ Lihat Harian Kompas, 16 April 2009

${ }^{9}$ Lihat Harian Kompas, 16 April 2009
} 
2. Faktor-faktor yang menghambat Implementasi Affirmative Action Kuota Perempuan dalam Partai Politik dan lembaga perwakilan rakyat di Wilayah Kota Malang

Topik masalah perempuan dalam politik dan pengambilan kebijakan telah menjadi isu global karena beberapa alasan: pertama, Pemerintah (mayoritas laki-laki) dengan perspektiflaki-laki (dan dengan sendirinya lebih banyak laki-laki) otomatis tidak dapat melegimitasi "prinsip pemerintahan oleh rakyat untuk rakyat" sebagai esensi demokrasi. Alasannya:(a).Hak-hak politik perempuan merupakan bagian integral dan tidak terpisahkan dari hak asasi manusia; (b).Bahwa dalam demokrasi pandangan dari kelompok-kelompok yang berbeda termasuk berbeda jenis kelamin dan jender harus dipertimbangkan dan diinformasikan setiap kebijakan; (c) Perempuan adalah separuh penduduk dunia (separuh dari jumlah penduduk di setiap negara), oleh karena itu demokrasi haruslah mempertimbangkan pendapat dari separuh penduduk ini.

Kedua, Karena dipercaya bahwa tidak ada satu kelompok orang pun yang dapat mengartikulasikan kepentingan dan kebutuhan kelompok perempuan dengan kualitas tertinggi selain kaum perempuan sendiri. Hal ini terutamajika menyangkut artikulasi kebutuhan-kebutuhan perempuan yang spesifik misalnya dalam masalah kekerasan terhadap perempuan, kesehatan reproduksi dan lain-lain. Demikian pula pada masalah-masalah dimana perempuan banyak berkepentingan, misalnya soal kesehatan, pendidikan dan masalah penyediaan pangan, kebijakan mengenai hal-hal tersebut dan bahkan kebijakan makro pertanian, kelautan, kehutanan, pembangunan kota, tidak dapat dibuat tanpa mengikutsretakan kaum perempuan dan memakai perspektif perempuan di dalamnya. Dengan demikian maka partisipasi perempuan dalam politik bukanlah sesuatu keistimewaan namun sebuah keperluan. ${ }^{10}$

Ketiga, Lebih jauh lagi kebutuhan-kebutuhan perempuan yang spesifik dan kepentingan-kepentingan hidup perempuan di atas, akan lebih jauh berhasil diagendakan oleh kaum perempuan sendiri daripada kaum laki-laki, dan keempat, Perempuan dianggap dapat membawa perubahan dalam gaya

${ }^{10}$ Florence Buteqwa dalam Nursyahbani Katjasungkana dan Liza Hadiz (editor), 1999. Laporan Independen kepada Komite PBB untuk Penghapusaan Diskriminasi terhadap Perempuan, Jakarta: LBH APIK dan nilai-nilai baru dalam politik dan juga dalam pembangunan. Peminggiran perempuan dalam politik dan pembangunan telah bertentangan dengan kenyataan bahwa mereka telah menunjukkan kemampuan luar biasa dalam mengelola ketahanan keluarga dan pemeliharaan kehidupan. Dengan kata lain bahwa peminggiran perempuan dalam arena publik berarti telah menyia-nyiakan bakat, kemampuan dan kearifan mereke dalam membuat keputusan. Pengalamannya sebagai penjaga dan pemelihara kehidupan telah memberikan kearifan kepada perempuan untuk melihat pembangunan sebagai suatu cara untuk mengatasi kemiskinan sekaligus melestarikan kehidupan dan lingkungan. ${ }^{11}$

Lycette menyebutkan ada empat faktor yang menjadi kendala partisipasi perempuan dalam urusan publik, yakni: (1) Perempuan menjalankan dua peran sekaligus, yaitu peran reproduktif serta peran produktif, di dalam maupun di luar rumah; (2) Perempuan relatif memiliki pendidikan lebih rendah dari pada laki-laki Tingkat pendidikan perempuan yang rendah dan perbedaan kesempatan yang diperoleh anak perempuan dan laki-laki terjadi di seluruh dunia;(3)Adanya hambatan budaya yang terkait dengan pembagian kerja secara seksual dan pola interaksi perempuan dengan laki-laki yang membatasi gerak perempuan; (4)Adanya hambatan legal bagi perempuan, seperti larangan kepemilikan tanah, larangan berpartisipasi dalam pendidikan atau program Keluarga Berencana tanpa persetujuan dari suami atau ayahnya. ${ }^{12}$

Dengan alasan-alasan tersebut maka masyarakat internasional sepakat untuk: pertama, menyatakan bahwa akses dan partisipasi perempuan dalam semua tingkat pengambilan keputusan sebagai hak fundamental perempuan; kedua, jumlah perempuan dalam pengambilan'keputusan harus mencapai suatu critical mass yakni $30 \%$ agar memberikan dampak yang signifikan baik terhadap perempuan maupun terhadap masyarakat.

Masalahnya adalah karena perempuan yang terjun di dunia politik juga mengalami hambatan kultural maupun struktural baik yang berkenaan dengan substansi kebijakan yang ada maupun meka-

\footnotetext{
${ }^{11}$ Ibid

12 Pendapat Lycette sebagaimana dikutip oleh Indriyani Suparno dkk, 2005. Masih dalam Posisi Pinggiran: Membaca tingkat Partisipasi Politik Perempuan di Kota Surakarta, Yogyakarta: SPEKHAM Surakarta bekerjasama dengan Pustaka Pelajar
} 
nisme pembuatan kebijakan itu sendiri. Kendala kiltural terkait dengan masih kentalnya budaya partriarkhi dalam masyarakat yang menetapkan pola dan peran sosial yang berbeda untuk laki-laki dan perempuan. Sosialisasi nilai-nilai kultural yang berasal dari idiologi gender ini membuat perempuan kurang percaya diri untuk memasuki dunia politik. Hal ini juga diperkuat oleh suatu persepsi yang salah dari kaum perempuan sendiri tentang pengertian politik sebagai sesuatu yang buruk, kotor, penuh kelicikan kekerasan dan intimidasi (yang pada umumnya dibentuk oleh pengalaman dan cara berpolitik laki-laki).

Sementara kendala struktural ditemui dalam sistem pemilu yang memperkecil peluang munculnya perempuan, kurangnya kandidat perempuan dalam partai politik yang tidak didukung pula dengan sistem pendidikan politik di dalam internal partai. Selain itu juga kendala eksternal berupa kelemahan di bidang sosial ekonomi, dimana kebayakan perempuan berpendidikan rendah, kemiskinan dan lemah secara ekonomi.

Dalam kaitan ini, ketua KPU Kota Malang menyatakan bahwa:

Pelaksanaan affirmative action kuota perempuan dalam partai politik dan lembaga perwakilan masih sulit terlaksana karena minimnya perempuan yang bersedia terjun dalam dunia politik dan masih kentalnya budaya patriarki dalam masyarakat yang menganggap politik sebagai dunia laki-laki. ${ }^{13}$

Senada dengan pernyataan tersebut diatas, Dewi Masyitah dari Fatayat NU Kota Malang menyatakan:

Ada beberapa faktor yang mempengaruhi belum efektifnya affirmative action kuota perempuan dalam parpol ataupun lembaga legislatif yakni; 1) kurangnya kapabilitas dan kapasitas mereka (perempuan calon legislatif), 2) masih besarnya pengaruh partai yang mempunyai aturan dan mekanisme yang masih membatasi aspirasi perempuan yang duduk dalam pengurus partai ataupun mejadi anggota lembaga legislatif, 3) sistem rekruitmen dari parpol yang terkadang hanya mencari kader karena punya basis massa atau cukup dikenal oleh banyak orang tanpa memperhatikan kapabilitas dan kapasitas mereka, sehingga akibatnya ketika mereka terpilih duduk dalam partai ataupun lembaga legislatif mereka kurang menyuarakan aspirasi perempuan, jadi selama ini keberadaan $30 \%$ perempuan dalam parpol dan lembaga legislatif hanya untuk meme-

${ }^{13}$ Wawancara dengan Ketua KPU Kota Malang Hendry, ST tanggal 24 Oktober 2010 nuhi syarat yang telah ditentukan oleh UU saja bukan untuk bisa menampung dan menyalurkan aspirasi perempuan. ${ }^{14}$

Sebagaimana diuraikan pada bagian sebelumnya bahwajumlah caleg terpilih pada Pemilu DPRD Kota Malang Tahun 2009 adalah sebanyak 34 caleg laki-laki (76\%) dan 11 caleg perempuan (24\%), sehingga berjumlah 45 orang caleg terpilih. Dengan demikian upaya affirmative action sebagaimana dimaksud UU No.10 Tahun 2008 dalam Pemilu DPRD Kota Malang Tahun 2009 tidak tercapai karena jumlah caleg perempuan terpilih masih di bawah quota $30 \%$ (dalam rangka keterwakilan perempuan parlemen Kota Malang).

Kurang terakomodasinya kaum perempuan dalam hak-hak politik misalnya antara lain disebabkan oleh (1) konteks politik yang didominasi oleh kaum laki-laki sehingga kepentingan politik perempuan kurang terakomodasi, (2) konteks sosial yang didominasi kaum laki-laki sehingga menghasilkan praktek-praktek maskulin (maskulininasi) dan (3) konteks budaya yang didominasi tradisi patriarkal yang menghasilkan kontruksi sosial tentang pembagian kerja laki-laki dan perempuan (berdasarkan seks).

Jika diperhatikan komposisi perempuan di parlemen memang kurang terwakili karena beberapa sebab dan serangkaian kendala yang membatasi kemajuan mereka. Misalnya, dalam komisi-komisi di parlemen perempuan cenderung memegang jabatan-jabatan yang secara tradisi dilihat sebagai jabatan-jabatan yang "lembut", yang mencerminkan pola tradisional, seperti pembagian tanggungjawab antara laki-laki dan perempuan..$^{15}$ Kendala lain yang menghalangi perempuan menjadi anggota parlemen antara lain:

(1) Berkaitan dengan konteks budaya yang masih sangat kental asas patriartikalnya. Persepsi yang sering dipegang yaitu dunia politik adalah dunia laki-laki dan tidak pantas bagi perempuan untuk menjadi anggota parlemen. Menurut Nadezha, budaya patriarki ini menciptakan "model maskulin" dalam kehidupan politik dan badanbadan pemerintahan hasil pemilu.

${ }^{14}$ Wawancara dengan Ketua Fatayat NU Kota Malang Dewi Masyitah tanggal 26 Oktober 2010

15 http://www.pikiran-rakyat.com/cetak/0803/18/teropong/ lainnya 03.htm 
Kenyataan bahwa selama ini laki-laki mendominasi dunia politik memformulasikan aturan dan permainan politik, dan laki-laki juga yang menentukan standar evaluasi. Kehidupan politik juga diorganisasi sesuai dengan norma-norma dan nilai-nilai laki-laki serta dalam beberapa kasus mengikuti gaya hidup laki-laki. Misalnya, solusi menang-kalah serta kompetisi dan konfrontasi dianggap lebih baik dari pada solusi penciptaan konsensus, saling menghormati dan kalaborasi.

(2) Berkaitan dengan proses seleksi dalam partai politik, yang hampir selalu dilakukan oleh lakilaki, pemimpin laki-laki dari partai-partai politik memiliki kesadaran kesetaraan gender yang rendah, sehingga memberi pengaruh yang tidak proposional terhadap politik partai, khususnya dalam hal gender. Dengan demikian, perempuan tidak memperoleh banyak dukungan dari partaipartai politik karena struktur kepemimpinannya didominasi oleh kaum laki-laki.

(3) Berkaitan dengan media yang berperan penting dalam membangun opini publik tentang pentingnya representasi perempuan di parlemen.

(4) Belum adanyajaringan antara organisasi massa, LSM, dan partai-partai politik untuk memperjuangkan representasi perempuan.

(5) Kemiskinan dan tingkat pendidikan perempuan yang rendah. Wajah kemiskinana adalah wajah perempuan. Perempuan miskin harus bekerja memasok kebutuhan rumah tangga, tetapi kerja mereka tidak dihitung secara ekonomi. Kemiskinan ini ikut menghambat partisipasi mereka dalam politik formal.

(6) Faktor keluarga yang berkaitan dengan persoalan izin dari pasangan. Banyak suami yang cenderung menolak istrinya melakukan aktifitas tanbahan diluar rumah, sedangkan kegiatankegiatan politik membutuhkan ketertiban yang tinggi dan dana yang besar. ${ }^{16}$

Walaupun beberapa partai sudah menyertakan dalam kepengurusan, namun di dalam platform partai untuk kaderisasi ataupun kepengurusan tidak pernah mensyaratkan keharusan adanya pengurus wanita

${ }^{16}$ Tim Cakrawala Timur, 2006. Partisipasi Politik Perempuan dalam Proses Pembuatan Kebijakan Publik di Daerah Jawa Timur, Surabaya: diterbitkan oleh Yayasan Cakrawala Timur bekerjasama dengan PGRI dan Uni Eropa, hlm. 15-16 (misal sebagai salah satu ketua). Kalaupun perempuan ada dalam prakteknya mereka lebih banyak ditempatkan pada posisi sebagai bendahara yang stereotip dengan pekerjaan perempuan.

Banyak sebab mengapa posisi perempuan dalam kepengurusan masih sangat marjinal. Dalam perpolitikan Indonesia, perempuan baru diperlukan ketika hendak pemilu, dan dijadikan sebagai jurkam perempuan untuk mencari dukungan dari perempuan yang notebene merupakan $50 \%$ pemilih.

Kultur politik yang eksploitatif ini akan menampakkan wajah politik kehadapan publik sebagai dimensi aktivitas yang sangat maskulin, keras, dan tidak ramah kepada kaum perempuan. Kesan ini menjadi salah sati penghalang bagi perempuan untuk memasuki ruang publik politik tersebut. Bahkan, eksploitasi dalam bentuknya yang lain adalah menjadikan perempuan sebagai aksesoris kampanye. Soal program atau platform politik partai menjadi nomor dua. Yang terpenting adalah bahwa perempuan bisa bernyanyi, cantik, goyang dan massa yang hadir bisa membludak.

Kesalahan pokok dari pengalaman empiris tersebut bisa diidentifikasi sebab-sebabnya, antara lain: pertama, .Parpol tidak memiliki pertautan idealisme yang termanifestasikan ke dalam platform partai dengan elemen kekuatan kemasyarakatan seperti perempuan. Parpol hampir tidak pernah melihat perempuan sebagai elemen kekuatan yang penting dan patut diperhitungkan. Kultur politik yang eksploitatifhanyamemandang perempuan sebagai aksesoris politik untuk memeproleh suara dalam pemilu.

Kedua, Kaderisasi dan rekrutmen politik yang terdapat pada anggaran dasar atau anggaran rumah tangga partai tidak memiliki gender sensitivity, karena pembuat kerangka kaderisasi dan rekrutmen itu sebagian besar adalah laki-laki yang sama sekali tidak memiliki kepekaan gender; Ketiga, .Perumusan kebijakan di partai sebagian besar adalah laki-laki, mengakibatkan perempuan dalam posisi yang amat lemah dalam pengambilan keputusan di tingkat partai. Akibatnya, bargaining position perempuan pun tidak menguntungkan dalam perumusan kebijakan. Bagaimanapun, dengan minimnya perempuan maka keterwakilan perempuan dalam perumusan kebijakan sangat kecil; dan keempat, .Politik senantiasa berada pada kecenderungan 
mengarus. Politik tidak sekedar formulasi kebijakan, tetapi juga ada dalam ruang kekuasaan untuk mendapatkan akses. Dengan demikian komitmen parpol pada pemberdayaan perempuan menjadi nomor dua. ${ }^{17}$

Disamping persoalan tersebut diatas, salah satu akar masalah yang dituding sebagai gagalnya implementasi affirmative action kuota perempuan adalah lahirnya putusan Mahkamah Konstitusi beberapa bulan menjelang Pemilu (09 April 2009), Mahkamah Konstitusi sebagai lembaga negara yang memiliki kewenangan melakukan pengujian undangundang terhadap Undang Undang Dasar mengeluarkan Putusan Nomor 22-24/PUU-VI/2008 tanggal 23 Desember 2008 yang menyatakan sistem pendaftaran calon tertutup bukanlah preferensi suara terbanyak sebagaimana diberikan pemilih dan merupakan pelanggaran hak pemilih untuk memilih wakil rakyat yang diinginkan. Sehingga Pasal 214 Huruf a sampai e Undang Undang Nomor 10 Tahun 2008 tentang Pemilu DPR, DPD, dan DPRD bertentangan dengan konstitusi dan karenanya tidak mempunyai kekuatan hukum mengikat.

Putusan MK menyatakan bahwa, "prinsip kedaulatan rakyat merupakan prinsip konstitusi yang sangat mendasar yang bukan saja memberi warna dan semangat pada konstitusi yang menentukan bentuk pemerintahan, tetapi juga dapat dipandang sebagai moralitas konstitusi yang memberi warna dan sifat pada keseluruhan undang-undang di bidang politik" (hlm. 102)

Berkaitan dengan putusan MK, Ketua Fatayat NU Kota menyatakan:

Terkait putusan dari MK ada dua pendapat, pertama merugikan bagi calon kader yang ternyata cukup representatif, mempunya kapabilitas dan kapasitas tapi tidak banyak dikenal oleh massa/kurang mempunyai basis massa. Kedua, menguntungkan, bagi calon yang sudah cukup dikenal/telah mempunyai basis massa, bahkan ada juga yang diuntungkan oleh sistem yakni lolos menjadi anggota legislatif karena mendapat sisa suara. ${ }^{18}$

Secara sistem pemilu, penentuan caleg terpilih berdasarkan suara terbanyak menegaskan sistem proporsional terbuka yang sebenarnya telah diatur dalam UU Nomor 10 Tahun 2008. Di samping itu,

${ }^{17}$ Ibid, hlm. 20-21

${ }^{18}$ Wawancara dengan Dewi Masyitah, Ketua Fatayat NU Kota Malang, 26 Oktober 2010 bagi seluruh pemangku kepentingan kepemiluan, sistem suara terbanyak lebih banyak manfaatnya. Bagi parpol, tidak perlu lagi menyiapkan mekanisme pernyataan surat pengunduran diri jika caleg dengan suara terbanyak tidak memenuhi syarat bilangan pembagi pemilih. Mekanisme demikian amat rentan potensi konflik yang bisa menjadi tumpukan perkara sengketa hasil pemilu di MK. Bagi KPU, pekerjaan menentukan caleg terpilih pun menjadi jauh lebih mudah.

Namun demikian, Terhadap Putusan MK ini, tidak semua aktivis perempuan menerimanya, Nursyahbani Katjasungkana misalnya menyebutkan bahwa Keputusan Mahkamah Konstitusi yang menentukan caleg dipilih berdasar suara terbanyak pada 22 Desember 2008, kurang empat bulan dari pelaksanaan pemilu 9 April 2009, disebut Nursyahbani sebagai "membunuh" perempuan. "Keputusan itu tidak kompatibel dengan UU Pemilu yang memakai sistem proporsional dengan akibat caleg bertarung dengan teman sendiri dalam satu parpol. Parpol tidak siap menentukan calegnya karena nama sudah harus masuk ke Komisi Pemilihan Umum sebelum jatuh keputusan MK itu. ${ }^{19}$

Terlepas dari berbagai kontroversi, inkonsistensi dan ambivalensi partai-partai politik dalam menyikapi sistem suara terbanyak sejak UU tersebut dibahas di DPR. Keputusan MK patut diapresiasi sebagai bentuk penghormatan terhadap suara rakyat. Putusan tersebut tidak hanya memutus oligarkhi pimpinan partai politikdalam penetapan calon anggota legislatif, tetapi juga mendorong para caleg untuk bekerja keras meraih dukungan dan simpati publik.

Pesan pokok kebijakan afirmatif adalah setiap orang dituntut memiliki kualitas tinggi agar bisa berperan dan berpartisipasi di panggung publik. keterwakilan suatu kelompok masyarakat (perempuan minoritas) di lembaga publik harus menunjuk pada standar tertentu untuk menjamin mutu dan kinerja. Dalam konteks konstatasi pemilu legislatif, putusan MK seyogyanya menjadi tantangan bagi para pembelahak-hak politik perempuan untukmembuktikan perempuan layak pilih bukan karena gender inequity, akan tetapi karena kualitas yang baik..$^{20}$

\footnotetext{
${ }^{19}$ Lihat Harian Kompas, 08 Mei 2009

${ }^{20}$ Amich Alhumami, 2009. "Mitos Kebijakan Afirmatif" artike dalam harian Kompas, 05 Februari 2009
} 
3. Strategi kaum perempuan dalam implementasi Affirmative Action Kuota Perempuan dalam Partai Politik dan lembaga perwakilan rakyat di Wilayah Kota Malang

Fenomena kelangkaan perempuan di dalam aktivitas publik, khususnya dalam politik di parpol, sangat disadari oleh kaum perempuan, terutama mereka yang memperjuangkan hak-hak perempuan, sehingga tak jarang muncul perdebatan persoalan dimana sebenarnya kedudukan perempuan, khususnya dalam negara. Perdebatan akan kedudukan dan peran perempuan tersebut selalu berkisar pada persoalan yang bergerak pada dua pendulum, yakni perempuan berkedudukan di dunia private (kerumahtanggaan) atau di dunia publik. Lebih-lebih ketika melihat fenomena bahwa beberapa perempuan bisa merangkap tiga peran, yakni peran bagi dirinya sendiri, keluarga dan masyarakat (publik), yang ketiga peran tersebut mampu dilakukan secara bersamaan oleh perempuan. Inilah yang acapkali disebut dengan triple burden bagi perempuan.

Dalam konteks melihat rentang waktu ini, kedua pandangan tersebut sebenarnya sangat dipengaruhi oleh gender bias, yakni bahwa kepentingan perempuan masih disepelekan, terutama di partai politik. Praktek politik masih menunjukkan bahwa parpol lebih dipahami sebagai struggle for power dari pada sebagai artikulator kepentingan. Oleh karena itu yang terjadi adalah platform partai politik yang ada selama ini baik pada masa orde lama, bahkan reformasi masih memperlihatkan betapa jauhnya gender sensitivity. Ini disebabkan platform partai politik selama ini merupakan produk dari mayoritas kaum laki-laki yang tidak memiliki gender sensitivity. Pada akhirnya, kepentingan perempuan tidak akan pernah terartikulasikan di parpol, dan ini berimbas juga pada produk politik DPR yang tidak memiliki gender sensitivity. ${ }^{21}$

Tidak memadainya ketentuan mengenai kuota dalam dua undang-undang politik (UU Pemilu dan UU Parpol) dalam menjamin aspirasi dan kepentingan kaum perempuan serta hadirnya putusan Mahkamah Konstitusi, mengharuskan kaum perempuan untuk mẹncari sebuah upaya lain yang dapat mendukung peningkatan keterwakilan politik perempuan dalam penyelenggaraan pemilu. Upaya

${ }^{21}$ Tim Cakrawala Timur, Op. Cit, hlm. 14 ini sangat dibutuhkan, karena sebagai sarana untuk mewujudkan kedaulatan rakyat, pemilu harus mampu menjamin prinsip keterwakilan, akuntabilitas, dan legitimasi.

Manurut Sali Susiana, selain sebagai wujud pelaksanaan demokrasi, pemilu menjadi penting bagi perempuan, karena: (1).Pemilu merupakan mekanisme yang dapat mempengaruhi tingkat keterwakilan perempuan dalam lembaga pembuat undang-undang (legislatif) dan kebijakan publik; (2) Keterwakilan perempuan pada lembaga-lembaga tersebut penting agar rancangan undang-undang (RUU) serta kebijakan publik yang dihasilkan memperhatikan kepentingan perempuan dan tidak diskriminatif terhadap perempuan; (3) Perempuan mempunyai kebutuhan khusus yang hanya dapat dipahami paling baik oleh perempuan sendiri; (4) Perempuan merupakan separuh lebih dari jumlah penduduk yang seharusnya mempunyai peran yang sangat menentukan dalam mewujudkan masyarakat adil dan demokratis; (5) Sama seperti laki-laki, perempuan mempunyai hak untuk mengambil bagian dalam pemerintahan negara, baik secara langsung maupun tidak langsung melalui wakil-wakil yang dipilih secara bebas. ${ }^{22}$

Berdasarkan wawancara yang dilakukan oleh tim peneliti kepada berbagai informan, terutama pimpinan Ormas dan NGO yang fokus pada advokasi perempuan berbagai kegiatan sebagai strategi kaum perempuan untuk meningkatkan keterwakilan perempuan adalah dengan dengan melakukan pendidikan politik pada perempuan pemilih, terutama mereka yang baru pertamakali memilih atau dikenal sebagai perempuan pemilih pemula.

Disamping kegiatan yang spesifik menyambut kegiatan pemilu, kaum perempuan juga melakukan berbagai kegiatan sebagai bentuk pemberdayaan perempuan. Seperti yang diungkapkan oleh Dewi Masyitah, ketua Fatayat NU Kota Malang:

Karena tidak mempunyai kader dalam partai maka cara Fatayat memperbaiki kebijakan yang tidak berpihak dari perempuan adalah dari luar sistem dengan cara mengajak komponen perempuan untuk bicara yang mana hasil dari pembicaraan tersebut di sampaikan kepada lembaga

${ }^{22}$ Sali Susiana, 2003. "Pendidikan Politik bagi Perempuan Pemilih: Strategi Menuju Keterwakilan Perempuan yang Lebih Berperspektif Gender" dalam Sali Susiana (Penyunting), 2003 Pemilu 2004: Analisis Politik, Hukum dan Ekonomi, Jakarta: P3I Sekjen DPR RI 
legisalatif untuk kemudian bisa mempengaruhi kebijakan yang mereka buat, contohnya dulu pada awalnya di kota malang anggaran untuk perempuan hanya 200 juta dan itupun hanya untuk daerah-daerah yang dekat wilayah kota tidak sampai menyeluruh wilayah kota Malang, kemudian fatayat mengumpulkan komponen perempuan di Malang untuk di ajak membicarakan kebijakan tersebut dengan tujuan adanya perubahan untuk menambah anggaran perempuan, pembahasan tersebut juga diikuti oleh Pusat Studi Wanita dari beberapa Universitas di kota Malang, seperti dari UIN, UB, UNMUH dan UM, dan dihadiri juga oleh Badan Otonom dari Fraksi Golkar, PKS dan PDI-P dengan didampingi oleh MCW, pembahasan tersebut dilakukan dalam bentuk talk show di radio swasta, kemudian hasil dari pembahasan tersebut di bawa ke lembaga legislatif dan juga dibawa ke sekkota, akhirnya kemudian dibuat kebijakan subsidi untuk posyandu sebesar 300 ribu, dan juga di adakan alokasi dana untuk kesehatan reproduksi, menurut beliau perempuan perlu diperhatikan karena PAD kota Malang terbesar dari perempuan. ${ }^{23}$

Khusus berkaitan dengan pendidikan politik bagi perempuan pemilih pemula dijadikan sebagai "target sasaran". Karena beberapa pertimbangan: Pertama, sebagai orang yang baru pertamakali akan mengikuti pemilu, mereka perlu dibekali dengan informasi yang cukup dan mendetail mengenai apa yang harus mereka lakukan. Kedua, sebagai perempuan, mereka juga perlu dibekali dengan informasi dan pengetahuan yang berkaitan dengan identitas mereka sebagai perempuan. Artinya, perlu dibuka wawasan bahwa hasil pilihan mereka secara tidak langsung nantinya akan mempengaruhi proses pengambilan keputusan yang akan diambil berkaitan dengan nasib mereka sendiri. Dengan demikian, seyogyanya mereka hanya memilih parpol yang benar-benar memiliki sensitifitas dan perspektif gender dalam program yang merek tawarkan. Hal ini sangat penting, mengingat jumlah penduduk perempuan tidak sedikit (lebih dari $50 \%$ dari total penduduk), sehingga jika pilihan mereka "tepat", diharapkan hasilnya akan signifikan bagi upaya peningkatan pemberdayaan perempuan di lembaga-lembaga politik, baik di tingkat lokal maupun tingkat nasional.

Pendidikan politik bagi perempuan menjadi begitu urgen untuk dilakukan karena lahirnya peraturan kuota perempuan malalui UU parpol dan pemilu seolah-olah menjadi berita baik bagi kaum

${ }^{23}$ Wawancara dengan Dewi Masyitah, Ketua Fatayat NU Kota Malangtanggal 26 Oktober 2010 perempuan. Memang, UU baru ini mengakui adanya kebutuhan untuk melibatkan perempuan dalam partai politik sebagai upaya agar perempuan bisa memperoleh akses yang lebih luas dalam pengambilan keputusan di dalam partai. ${ }^{24}$

Akan tetapi, karena penekanan terhadap keterlibatan perempuan dalam pengambilan keputusan partai tidak dinyatakan secara eksplisit, maka tidak ada jaminan bahwa penyertaan minimal $30 \%$ perempuan di dalam keanggotaan partai akan otomatis mengubah mindset partai untuk berpihak kepada perempuan. Ketidaktegasan aturan UU mengenai keterwakilan perempuan dalam pengambilan keputusan partai menyebabkan penekanan angka $30 \%$ menjadi sumir. Fakta ini, tak pelak, menimbulkan kesan bahwa kebijakan kuota yang baru ini sebenarnya lemah.

Menurut Laila Kholid, peraturan yang melulu fokus pada angka melalui kuota tidak akan berarti apa-apa jika tidak diperkuat dengan aksentuasi pada perluasan akses dan keterlibatan perempuan (women's access and engagement). Bila tidak, hal ini dapat menggiring kebijakan kuota pada jebakan yang disebut Carol Bacchi sebagai "the politic of presence" atau "politik kehadiran", yakni sebuah kebijakan yang merasa cukup dengan kehadiran kaum perempuan dalam lembaga politik tanpa perlu secara serius menelusuri apakah kehadiran tersebut telah dan akan berkontribusi bagi perubahan kebijakan yang lebih gender-aware..$^{25}$

Dalam perspektif Feminist Legal Theory berbagai persoalan ketidakberdayaan dan diskriminasi terhadap perempuan disebabkan oleh tidak adanya netralitas hukum seperti yang diyakini oleh pemikir positivisme hukum. Bagi feminis, hukum yang diyakini netral dan obyektifoleh teori positivisme hukum sebenarnya tidak mungkin ada. Sebab disadari atau tidak berbagai aturan hukum dibuat dalam perspektif patriarki dan dengan demikian lebih melindungi pria daripada perempuan.

Menurut Ratna Batara Munti sejauh berkaitan dengan perempuan sistem hukum yang berlaku masih cenderung diskriminatif. Meski dari substansi hukum, ketentuan mengenai hak asasi manusia

\footnotetext{
${ }^{24}$ Laila Kholid Alfirdaus, 2008. "Kebijakan Setengah Hati Kuota Perempuan dalam Partai Politik dan Parlemen" Artikel dalam Jurnal Konstitusi Volume 5, Nomor 2, November 2008. hlm. 145-159 ${ }^{25}$ Ibid
} 
(HAM) berikut jaminan perlindungan dan penegakan Jleh negara telah ditegaskan dalam Amandemen UUD 1945 dan Undang Undang Nomor 39 tahun 1999 tentang HAM, namun menjamin penegakannya bagi kaum perempuan dan kaum marginal lainnya karena konstruksi sosial budaya yang menghambat secara psikologis dan sosial. Buktinya dalam banyak kasus, masih sering dijumpai kaum perempuan yang mengalami perlalakuan diskriminatif serta mendapatkan kekerasan semata-mata karena jenis kelaminnya. ${ }^{26}$

Kedepan nampaknya tetap dibutuhkan kebijakan-kebijakan baru yang lebih progresifdan memihak kepeda situasi, kebutuhan dan kepentingan perempuan. Dan agenda pembaruan menurut Konvensi Penghapusan Segala Bentuk Diskriminasi Terhadap Perempuan (CEDAW) PBB yang telah diratifikasi pemerintah melalui UU Nomor 7 tahun 1984, merupakan tanggungjawab negara.

\section{Penutup}

Berdasarkan temuan penelitian dan pembahasan pada bab-bab sebelumnya, maka dapat diambil kesimpulan dan saran sebagai berikut:

\section{Kesimpulan}

1. Dalam penyelenggaraan pemilu anggota legislatif tahun 2009 di Kota Malang terdapat 793 orang calon anggota legislatif tetap, yang terdiri atas 528 laki-laki dan 265 perempuan. Sehingga ratarata prosentase caleg perempuan seluruh partai politik tersebut adalah $33 \%$, dan pada umumnya memang nampak bahwa parpol memiliki prosentase di atas quota $30 \%$.

Implementasi amanat Undang Undang Pemilu dan Undang Undang Partai politik yang mensyaratkan adanya tindakan Affirmative action kuota perempuan dalam Partai politik dan lembaga perwakilan rakyat daerah di wilayah Kota Malang menunjukkan bahwajumlah caleg terpilih pada Pemilu DPRD Kota Malang Tahun 2009 adalah sebanyak 34 caleg laki-laki (76\%) dan 11 caleg perempuan (24\%), sehingga berjumlah 45 orang caleg terpilih. Dengan demikian upaya affirmative action sebagaimana di-

${ }^{26}$ Ratna Batara Munti, 2005 “Advokasi Kebijakan (Legislasi) bagi Kepentingan Perempuan" tulisan artikel dalam Jurnal Hukum Jentera Edisi ke 10-tahun III Oktober 2005 diterbitkan Pusat Studi Hukum dan Kebijakan Indonesia Jakarta, hlm. 168-178 maksud UU No.10 Tahun 2008 dalam Pemilu DPRD Kota Malang Tahun 2009 tidak tercapai karena jumlah caleg perempuan terpilih masih di bawah quota $30 \%$.

2. Faktor-faktor yang menyebabkan kurang optimalnya pelaksanaan tindakan affirmative action dalam partai politik dan lembaga perwakilan di Kota Malang disebabkan oleh (1) konteks politik yang didominasi oleh kaum lakilaki sehingga kepentingan politik perempuan kurang terakomodasi, (2) konteks sosial yang didominasi kaum laki-laki sehingga menghasilkan praktek-praktek maskulin (maskulininasi) dan (3) konteks budaya yang didominasi tradisi patriarkal yang menghasilkan kontruksi sosial tentang pembagian kerja laki-laki dan perempuan.

Disamping faktor-faktor tersebut diatas, faktor lain yang dituding sebagai gagalnya implementasi affirmative action kuota perempuan adalah lahirnya putusan Mahkamah Konstitusi yang mensyaratkan penentuan calon anggota legislatif berdasarkan suara terbanyak, tidak berdasarkan nomor urut calon.

3. Strategi yang dilakukan oleh kaum perempuan dalam rangka implementasi affirmative action kuota perempuan dalam partai politik dan lembaga perwakilan daerah di wilayah Kota Malang adalah dengan melakukan pendidikan politik bagi perempuan pemilih dan strategi lain berupa advokasi kebijakan agar lebih memihak kepada aspirasi dan kepentingan perempuan.

\section{Saran}

Adapun saran dan rekomendasi yang dapat dikemukakan adalah:

1. Sebagai suatu tindakan sementara yang bersifat istimewa tindákan affirmative action kuota perempuan tetap dibutuhkan bagi kaum perempuan Indonesia yang berangkat dari posisi yang distreotip oleh budaya tidak setara dengan kaum laki-laki. Akan tetapi keterwakilan suatu kelompok masyarakat (perempuan minoritas) di lembaga publik harus menunjuk pada standar tertentu untukmenjamin mutu dan kinerja. Dalam konteks konstatasi pemilu legislatif, putusan MK seyogyanya menjadi tantangan bagi para pembela hak-hak politik perempuan untuk membuktikan perempuan layak pilih bukan karena 
gender inequity, akan tetapi karena kualitas yang baik.

2. Kedepan nampaknya tetap dibutuhkan kebijakan-kebijakan baru yang lebih progresif dan memihak kepeda situasi, kebutuhan dan kepentingan perempuan. Dan agenda pembaruan menurut Konvensi Penghapusan Segala Bentuk Diskriminasi Terhadap Perempuan (CEDAW) PBB yang telah diratifikasi pemerintah melalui UU Nomor 7 tahun 1984, merupakan tanggungjawab negara

\section{Daftar Pustaka}

Buku-Buku:

Asfar, M. (Editor), 2002. Model-Model Sistem Pemilihan di Indonesia, Surabaya: Pusdeham bekerjasama dengan Kemitraan

Ashiddiqie, Jimly, 1996. Pergumulan Peran Pemerintah dan Parlemen dalam Sejarah: Telaah Perbandingan Konstitusi Berbagai Negara, Jakarta: UI Press

, 1994. Gagasan Kedaulatan Rakyat dalam Konstitusi dan Pelaksanaannya di Indonesia, Jakarta: Ichtiar Baru Van Hoeve , 2005. Hukum Tata Negara dan Pilarpilar Demokrasi, Jakarta: Konpress , 2005. Konstitusi dan Konstitusionalisme Indonesia, Jakarta: Konpress , 2006. Pengantar Ilmu Hukum Tata Negara (jilid II), Jakarta: Konpres

Budiarjo, Miriam, 2008. Dasar dasar Ilmu Politik (Edisi Revisi), Jakarta: Gramedia Pustaka Utama

Dahl, Robert A. 1979. "procedural democracy" dalam P. laslett dan j. Fishkin (ed), Philosophy, politics and society, New Haven Yale University Press

Danardono, Donny, 2006. "Teori Hukum Feminis: Menolak Netralitas Hukum, Merayakan difference dan Anti-Essesialisme" dalam Sulityowati Irianto, (editor), 2006. Perempuan dan Hukum, Menuju Hukum yang Berperspektif Kesetaraan dan Keadilan, Jakarta: diterbitkan atas kerjasama nzaid dengan The Convention Watch, UI dan YOI
El Muhtaj, Majda, 2008. Dimensi-Dimensi HAM, Mengurai Hak Ekonomi, Sosial dan Budaya, Jakarta: PT. RajaGrafindo Persada, hlm. 235

Fakih, Mansour, 1999. Analisis Gender dan Transformasi Sosial, Yogyakarta: Pustaka Pelajar , dkk, 1996. Membincang Feminisme: Diskursus Gender Perspektif Islam, Surabaya: Risalah Gusti

Gaffar, Afan, 2000. Politik Indonesia, Transisi Menuju Demokrasi, Yogyakarta: PustakaPelajar

Huda, Ni'matul, 2005. Negara Hukum, Demokrasi \& Judiciel Review, Yogyakarta: UII Press Indriyani Suparno dkk, 2005. Masih dalam Posisi Pinggiran: Membaca tingkat Partisipasi Politik Perempuan di Kota Surakarta, Yogyakarta: SPEK-HAM Surakarta bekerjasama dengan Pustaka Pelajar

Jackson, Robert J., Doreen Jackson, 1997. A Comparative Introduction to Political Science, New Jersey: Prentice Hall

Kasim, Ifdhal \& Johanes da Masenus Arus (Editor), 2001. Hak Sipil dan Politik, Esai-esai Pilihan (buku 1), Jakarta: ELSAM

Madjid, Nurcholish, 1997. Tradisi Islam: Peran Dan Fungsinya Dalam Pembangunan Di Indonesia, Jakarta: Paramadina

Magnis-Suseno, Franz, 1997. Mencari Sosok Demokrasi, Sebuah Telaah Filosofis, Jakarta: PT Gramedia Pustaka Utama

Miles, M. B. dan M. Huberman.1992. Analisis Data Kualitatif, Jakarta: Penerbit UI Press

Mulyosoedarmo, Soewoto, 2004. Pembaharuan Ketatanegaraan Melalui Perubahan Konstitusi, Malang: kerjasama Asosiasi HTN \& HAN Jatim dan Intrans Publishing

Nurtjahyo, Hendra, 2005. Ilmu Negara, Pengembangan Teori Bernegara dan Suplemen, Jakarta: PT. Raja Grafindo Persada

Nursyahbani Katjasungkana dan Liza Hadiz (editor), 1999. Laporan Independen kepada Komite PBB untuk Penghapusaan Diskriminasi terhadap Perempuan, Jakarta: LBH APIK

Sali Susiana, 2003. "Pendidikan Politik bagi Perempuan Pemilih: Strategi Menuju Keter- 
wakilan Perempuan yang Lebih Berperspektif Gender" dalam Sali Susiana (Penyunting), 2003.

Pemilu 2004: Analisis Politik, Hukum dan Ekonomi, Jakarta: P3I Sekjen DPR RI

Safa'at, Rachmad, dkk, 1998. Buruh Perempuan: Perlindungan Hukum dan HAM, Malang: Penerbit IKIP Malang

Sirajuddin, dkk, 2009. DPRD: Peran dan Fungsi dalam Dinamika Otonomi Daerah, Malang: Setara Press

Smit, Rhona K. M., dkk, 2008. Hukum Hak Asasi Manusia, Yogyakarta: Pusat Studi HAM UII Yogyakarta

Surbakti, Ramlan, 1994. Memahami Ilmu Politik, Jakarta: PT. Gramedia Widiasarana Indonesia

Thaib, Dahlan, 2000. DPR Dalam Sistem Ketatanegaraan Indonesia, Yogyakarta: Liberty

Tim Cakrawala Timur, 2006. Partisipasi Politik Perempuan dalam Proses Pembuatan Kebijakan Publik di Daerah Jawa Timur, Surabaya: diterbitkan oleh Yayasan Cakrawala Timur bekerjasama dengan PGRI dan Uni Eropa

\section{Makalah/Jurnal/Media Massa:}

Alfirdaus, Laila Kholid, 2008. "Kebijakan Setengah Hati Kuota Perempuan dalam Partai Politik dan Parlemen" Artikel dalam Jurnal Konstitusi Volume 5, Nomor 2, November 2008. hlm. 145-159

Eep Saefulloh Fatah, 2009. "Dosa Besar Pemilu 2009" artikel Opini dalam Harian Kompas tanggal 14 April 2009

Harian Kompas, 2008. "Menghapus Diskriminasi yang Mengatasnamakan Demokrasi" oleh NinukM. Pambudi dan MariaHartiningsih yang dimuat tanggal 08 Mei 2008, hlm. 33

Harian Kompas, Rubrik Fokus tanggal 04 Maret 2006

Harian Kompas, Tanggal 08 Mei 2008

http://www.ipu.org,

Irianto, Sulityowati, 2006. "Apakah Hukum Boleh 'berpihak'? Sebuah Pertanyaan Perempuan" Artikel dalam Jurnal Perempuan Nomor 49, Tahun 2006, hlm. 31-45

Jurnal Perempuan 45, 2006 dengan tema "Sejauh Mana Komitmen Negara terhadap
Diskriminasi Perempuan", Jakarta: Yayasan Jurnal Perempuan

Jurnal Perempuan Nomor 49, Tahun 2006. "Hukum Kita Sudahkah Melindungi" diterbitkan Yayasan Jurnal Perempuan

Joko Widarto, 2009. "Implikasi Hukum Putusan MK Nomor 22-24/PUU-VI/2008 terhadap Upaya Affirmative Action dalam UU No. 10 Tahun 2008 di Kota Malang" artikel dalam Jurnal Konstitusi, kerjasama MK RI dengan PKK Univ. Kanjuruhan Malang, Vol. II No. 1, Juni 2009

Legowo, T. A., 2007. "Pemilihan Umum dan Perwakilan Politik" Artikel dalam Jurnal Hukum Jentera, Edisi 16 tahun IV, April Juni 2007

Mahendra, A.A. Oka, 2008. "Paradigma Baru UU Nomor 2 Tahun 2008 tentang Partai Politik" artikel dalam Jurnal Legislasi Indonesia, Vol. 5 No. 1 Maret 2008

Munir, Lily Zakiyah, 2009. "Tantangan Kuota Perempuan" Artikel dalam Harian Kompas, Senin, 30 Maret 2009.

Munti, Ratna Batara, 2005 “Advokasi Kebijakan (Legislasi) bagi Kepentingan Perempuan" tulisan artikel dalam Jurnal Hukum Jentera Edisi ke 10-tahun III Oktober 2005 diterbitkan Pusat Studi Hukum dan Kebijakan Indonesia Jakarta, hlm. 168-178

Razali Ritonga, 2009. "Momentum Sensus Penduduk 2010" artikel opini dalam harian Kompas tanggal 21 April 2009

Sri Moertiningsih Adioetomo, 2009. "Karut DPT Pemilu 2009" artikel opini dalam Harian Kompas tanggal 14 April 2009

http://www.pikiran-rakyat.com/cetak/0803/18/ teropong/lainnya03.htm

Harian Kompas 08 April 2002

Harian Kompas 19 Desember 2003

Harian Kompas, 16 April 2009

\section{Peraturan Perundang-undangan:}

Republik Indonesia, UUD Negara Republik Indonesia Tahun 1945 dan perubahannya

Republik Indonesia, Undang Undang Nomor 7 Tahun 1984 tentang Pengesahan Konvensi 